Peter Čuka

https://orcid.org/0000-0001-8044-2746

Uniwersytet Pedagogiczny w Krakowie Instytut Geografii cukapeter@gmail.com

Bohuslava Gregorová

https://orcid.org/0000-0002-8544-9493

Uniwersytet Mateja Bela

Wydział Geografii i Geologii

Bohuslava.Gregorova@umb.sk

\title{
SATYSFAKCJA KLIENTÓW SŁOWACKICH UZDROWISK: STUDIUM PRZYPADKU UZDROWISK W MIEJSCOWOŚCIACH RAJECKÉ TEPLICE, PIESZCZANY I BRUSNO'
}

\begin{abstract}
Abstrakt: Niniejsza praca ma na celu zaprezentowanie modelu satysfakcji klienta na przykładzie wybranych sytuacji z branży uzdrowiskowej. Jest to w szczególności omówienie zagadnienia satysfakcji gości słowackich uzdrowisk w miejscowości Rajecké Teplice w porównaniu do zadowolenia z wizyt w kurortach w Pieszczanach i Brusnie. Satysfakcja klienta jest zagadnieniem wieloaspektowym, które można poddać ocenie głównie przy użyciu metod jakościowych. W artykule zamieszczono oryginalną ankietę satysfakcji klienta. Motywacją autorów było zwrócenie uwagi na subiektywną naturę badań jakościowych dotyczących satysfakcji klienta - szczególnie w obszarze obiektów usługowych, w tym wypadku wybranych słowackich uzdrowisk - oraz na związane z nimi trudności. Wynik badań stanowi jednocześnie porównanie granic indywidualnej satysfakcji klienta w heterogenicznych miejscowościach uzdrowiskowych. Pieszczany są bowiem najważniejszym ośrodkiem uzdrowiskowym na Słowacji, Rajecké Teplice - średniej wielkości miastem uzdrowiskowym, Brusno zaś - niewielkim, nieco gnuśnym uzdrowiskiem. Klienci mieli za zadanie ocenić je oraz stworzyć listę „top 12" - uszeregować spa na podstawie subiektywnego odczucia satysfakcji w odniesieniu do ich otoczenia, oferowanych usług, opieki zdrowotnej i atrakcji.
\end{abstract}

Słowa kluczowe: uzdrowisko Rajecké Teplice, uzdrowisko Pieszczany, uzdrowisko Brusno, satysfakcja klienta, składniki satysfakcji klienta.

\section{WSTĘP}

Na Słowacji istnieją 23 oficjalne ośrodki uzdrowiskowe (rys. 1): Bardejów-Zdrój, Bojnice, Brusno, Číž, Dudince, Górny Smokowiec, Dolny Smokowiec, Szczyrbskie Jezioro, Wyżnie Hagi, Łuczywna, Lúčky, Nimnica, Rajecké Teplice, Sklené Teplice, Turčianske Teplice, Trenczyńskie Cieplice, Štós, Sliač, Drużbaki Wyżne, Novolubovnianske kúpele, Smrdáky, Narodowe Centrum Rehabilitacji Kováčová, Pieszczany. Woda jest podstawowym czynnikiem determinującym lokalizację działań społeczno-gospodarczych mieszkańców kraju. Źródła termalne i mineralne były znane na Słowacji już od czasów prehistorycznych. W literaturze uwydatnione są obydwa rodzaje wód, tj. zarówno źródła mineralne, jak i termalne (zob. np.: Bel, 1735; Čuka, 2004; Gregorová, 2010; Heksch, 1881; Hydrological and phenological conditions of Czechoslovakia, 1970).
Usługi oferowane w uzdrowiskach słowackich są na różnym poziomie, ale we wszystkich tych ośrodkach ważna jest satysfakcja klienta. Uwzględnione $\mathrm{w}$ badaniu opinie pochodzą z następujących materiałów źródłowych:

- oceny poszczególnych uzdrowisk,

- opinie firm oferujących ubezpieczenia zdrowotne,

- badania terenowe.

Wyniki badań różnią się od siebie w zależności od tego, które lata obejmują jak również od źródeł, na których były oparte, oraz od obranej metodologii.

W niniejszej pracy zostały wyszczególnione punkty wyjścia do opracowania metodologii badawczej zastosowanej do oceny satysfakcji klientów. Badanie satysfakcji klientów uzdrowiska Rajecké Teplice $(\mathrm{n}=278)$ ma charakter wzorcowy. Autorzy zaprezentowali również 


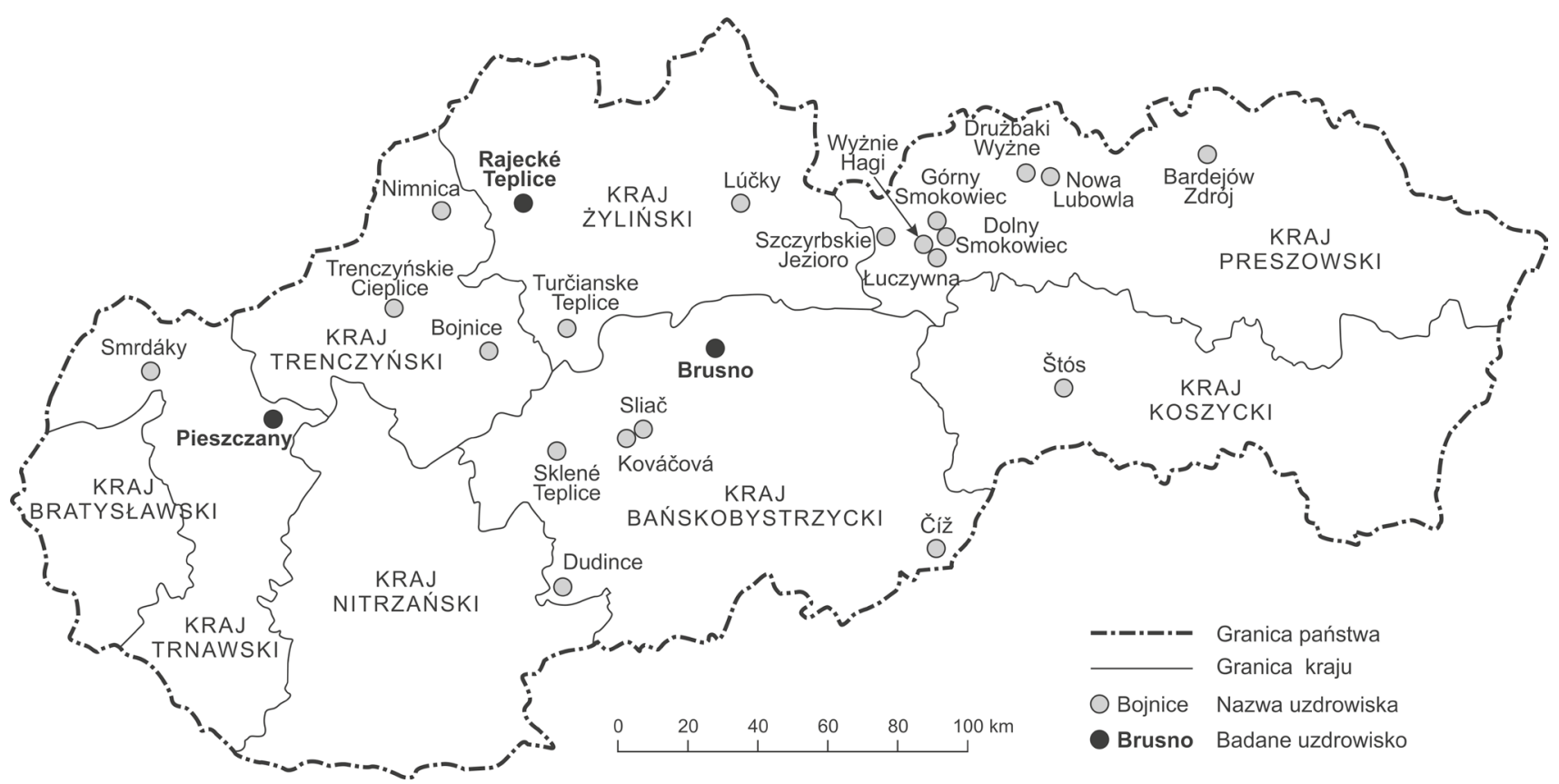

Rysunek 1. Lokalizacja słowackich uzdrowisk

Źródło: opracowanie własne

porównanie wyników badań satysfakcji klientów w uzdrowisku Brusno $(n=64)$ i w najsłynniejszym słowackim uzdrowisku w Pieszczanach ( $\mathrm{n}=327)$.

Badania terenowe zostały przeprowadzone wśród gości i klientów na podstawie kilku źródeł. Dotychczas stworzono następujące rankingi wybranych słowackich uzdrowisk według poziomu satysfakcji klientów:

- ranking na podstawie ubezpieczenia zdrowotnego (Dôvera zverejnila proý rebríček kúpel'ov, 2009): 1. Brusno, 2. Dudince, 3. Nimnica, 4. Číž, 5. Pieszczany;

- ranking na podstawie badań innych naukowców (Nagyová, 2009): 1. Brusno, 2. Číž, 3. Bardejów-Zdrój, 3. Pieszczany, 4. Nimnica, 5. Dudince, 6. Sliač;

- ranking na podstawie badań terenowych przeprowadzonych przez autorów (Čuka, Matušíková, Šenková, 2013): 1. Brusno, 2. Pieszczany, 3. Rajecké Teplice, 4. Kováčová, 5. Bardejów-Zdrój.

\section{METODY I CELE BADANIA}

Niniejsza praca ma na celu zaprezentowanie modelu satysfakcji klientów na przykładzie wybranych sytuacji z branży uzdrowiskowej. Artykuł stanowi w szczególności omówienie zagadnienia satysfakcji klientów i gości słowackich uzdrowisk, zwłaszcza w miejscowości Rajecké Teplice. Kolejnym celem pracy jest ukazanie złożoności procesu decyzyjnego, który ma bezpośredni wpływ na poziom satysfakcji klientów. Ponadto w tekście zamieszczono ankietę oraz porównanie wyników badań satysfakcji klientów, przeprowadzonych w miejscowościach uzdrowiskowych Pieszczany i Brusno na podstawie stworzonej przez autorów metodologii. Zestawienie tych wyników ma wartość porównawczą.

Na rynku mieszanym (ang. mixed market) - w przestrzeni regulowanej gospodarki rynkowej Unii Ekonomicznej, w której znajduje się Słowacja - podaż, popyt i zysk należą do najbardziej decydujących sił rynkowych. Zysk wyraża się ilościowo (nominalnie) oraz jakościowo. Satysfakcję klienta można zaliczyć do jakościowych elementów składowych zysku. Jest ona wartością subiektywną i może przybierać różne formy, takie jak satysfakcja emocjonalna lub wielokrotny ponowny zakup produktu, który wywołał uczucie zadowolenia. Na Słowacji satysfakcję emocjonalną mierzy się obecnie m.in. w środowisku bankowym, przykładowo: Tatra Banka używa inteligentnego oprogramowania (AI - sztuczna inteligencja), które potrafi samodzielnie rozpoznać emocje według ośmiostopniowej skali (Tatrabanka používa AI technológiu, 2017).

W słowackiej literaturze naukowej badania satysfakcji klientów uzdrowisk często są pomijane. W Polsce studia takie przygotowuje się przy użyciu modelu KANO (Walas, 2018). Obszerne badania jakościowe w tym zakresie zostały przeprowadzone przez Szymańską (2013). Z prac różnych badaczy wynika, że satysfakcja w dużej mierze odzwierciedla się w zachowaniach klienta (Gotowska, Jakubczak, 2012; Mont, Plepys, 2014; Rudnicki, 2015; Zmyślony, Nawrot, 2009). Istnieje kilka sposobów rozumienia i definiowania zagadnienia satysfakcji klienta. W normie jakości STN EN ISO 9000:2006 wyjaśniono pojęcie satysfakcji klienta jako określony poziom jakości, przy którym zostały spełnione wymagania klienta. Można wysnuć z tego wniosek, iż satysfakcja klienta jest powiązana z jego emocjami oraz uczuciami. Te zaś 
są trudne do uchwycenia. Satysfakcja jako całość składa się z jednostkowych odczuć, które mogą mieć różną wagę. Pomiar satysfakcji klientów jest jednym z narzędzi, dzięki którym można poznać ich reakcje i opinie. Zadanie to jest zaliczane do zarządzania jakością danej organizacji. Jednym z działań sprzyjających osiagnnięciu większej satysfakcji przez klienta jest skupienie na nim uwagi. Zorientowanie na klienta oznacza, że trzeba indywidualnie podchodzić do każdej osoby (Foster, 2002; Kärnä, 2014; Rudnicki, 2015).

\section{METODOLOGIA PRZETWARZANIA DANYCH}

Satysfakcja wyraża się poprzez złożone, wieloaspektowe zjawiska. Rudnicki (2010) opisał zewnętrzne (społeczno-kulturowe i gospodarcze) oraz wewnętrzne (psychologiczne, osobowo-demograficzne) czynniki zachowań konsumentów. Owe czynniki kształtują również satysfakcję klienta.

Autorzy niniejszego artykułu wyszli w swoich rozważaniach od złożoności procesów psychicznych i poznawczych, najlepiej opisanych przez Evansa (1982, 2004). Wiedza ta została rozwinięta na polu badań psychologicznych przez Beacha i Connolly'ego (2005). Autorzy posiłkowali się również wynikami nowszych badań społeczno-gospodarczo-marketingowych, uzyskanymi przez Fostera (2002) i Kärnu (2014).

Ostatecznie autorzy zaprezentowali własna, oryginalną metodologię, którą zastosowali do oceny satysfakcji klientów uzdrowisk. Przy jej wykorzystywaniu wzięli pod uwage takie kwestie, jak:

- opieka zdrowotna - jest to absolutny priorytet dla wszystkich uzdrowisk, ponieważ ich głównym celem jest poprawa zdrowia klientów;

- usługi biznesowe - w ciągu kilku ostatnich dekad uzdrowiska przekształciły się w centra handlowe i kongresowe oraz centra usług biznesowych;

- potencjał geograficzny uzdrowiska - składają się na niego walory urbanistyczne oraz walory środowiska naturalnego w bezpośrednim otoczeniu uzdrowiska;

- inne wartości natury społeczno-kulturowej, do których zaliczyć można obecność klientów międzynarodowych oraz formy aktywności towarzyskiej.

Istnieją dwa rodzaje satysfakcji: racjonalna i emocjonalna. Satysfakcja emocjonalna (lub jej brak) wyraża się poprzez pozytywne uczucia wynikające z użycia danego produktu (w tym wypadku korzystania z usług uzdrowiskowych) bądź poprzez wiele negatywnych uczuć, takich jak: niezadowolenie, zastrzeżenia, złe emocje itp. Rudnicki (2010) opisuje satysfakcję emocjonalną jako „zaspokojenie potrzeb emocjonalnych i estetycznych". Oczywiście głównym elementem składowym satysfakcji emocjonalnej w przypadku korzystania z uzdrowisk jest zadowolenie z terapeutycznych efektów pobytu.

Satysfakcja racjonalna z kolei może zostać wyrażona słownie, np. w sondażu, w formie pisemnego zapytania, jako wyrazy wdzięczności (np. dla personelu), jednak głównie przejawia się ona jako powtórne wybranie danego produktu (w tym wypadku usług uzdrowiskowych). Satysfakcja racjonalna jest więc formą zysku z produktu (Evans, 1982).

Obydwa rodzaje satysfakcji mają różne poziomy w strukturze produktu, np. w przypadku usług gastronomicznych, noclegowych, medycznych czy dodatkowych. Odzwierciedlają one jednak również złożoność miejscowości uzdrowiskowych i ich zaplecza (kulturę, architekturę, infrastrukturę biznesowa, walory środowiska naturalnego itd.).

Wszystkie wymienione formy satysfakcji mogą być wynikiem procesów decyzyjnych. Ostatnie badania pokazuja, iż procesy decyzyjne ludzi, a więc również klientów uzdrowisk, są o wiele bardziej złożone, niż uważano kilka dekad temu. Ważne jest, by zrozumieć, iż w zobiektywizowanych badaniach dotyczących satysfakcji należy wziąć pod uwage procesy neuropsychiczne, wchodzące w zakres neuropsychologii oraz - częściowo - neuromarketingu, będącego gałęzią ekonomii. Na dualizm myślenia zwraca również uwagę Evans $(1982,2004)$ w swoich klasycznych pracach, które później rozwinęło wielu autorów, w tym Bačová (2010), Beach, Connolly (2005), Glimcher, Fehr (2008). We wspomnianych pracach podkreślano również warunkowość myślenia i podejmowania decyzji, które mają kluczowe znaczenie dla odczuwania satysfakcji. Warunkowość myślenia wyraża się również poprzez wpływ bodźców finansowych, preferencje osobiste (oraz wspomnieniowe), zdolność organizmu do wytwarzania dopaminy itd. (Bačová, 2010).

Dwoistość myślenia wyraża się np. poprzez podejmowanie kontrastowych decyzji, które mogą być albo automatyczne, implicytne i niekontrolowane, albo eksplicytne, świadome i kontrolowane (Evans, 1982). W praktyce ów dualizm oznacza, iż wiele elementów produktu uzdrowiskowego jest narażonych na tendencyjne, niekognitywne, niekontrolowane bądź emocjonalne wpływy ludzkiego myślenia. Dlatego też wyniki badań dotyczących satysfakcji klientów będą zawsze w dużym stopniu zdeterminowane przez owe dysproporcje. Zagadnienie neuromarketingu, a w szczególności badania psychologiczne oparte na „skanowaniu mózgu", wykracza jednakże poza zakres niniejszej pracy.

Rzecz jasna, autorzy artykułu chcieli uzyskać wyniki ankiety dotyczącej satysfakcji od osób zajmujących się public relations w uzdrowiskach objętych badaniem, ale zostali odesłani do napisanych przez gości recenzji dostępnych w Internecie, np. na stronach Rajecké Teplice liečebný pobyt (2019) lub Tripadvisor (2019). Należy 
jednak pamiętać, że wyniki ankiet publikowane w Internecie często bywają filtrowane (oceny negatywne mogą być usuwane). Podobnie wartość takich tekstów jest zazwyczaj ograniczona - klienci zamieszczają jedynie częściową ocenę zjawisk, które im się podobają.

Można pokusić się o stwierdzenie, iż zarząd danego kurortu monitoruje wewnętrznie informacje zwrotne od klientów związane z ich satysfakcja, jednak badania oparte na kontakcie osobistym z odpowiedzialnymi członkami kadry kierowniczej wykazały, iż są oni bardziej skupieni na wynikach finansowych i zyskach. Udowodniono, że brakuje zainteresowania głębszą analizą satysfakcji klientów uzdrowisk. Przesłanką takiego zachowania jest fakt, iż obiektywny pomiar satysfakcji klienta w dużej mierze zależy od czynników przeanalizowanych w poprzednich partiach niniejszego artykułu.

Po dokonaniu analizy obecnego stanu badań dotyczących satysfakcji klientów w uzdrowiskach można stwierdzić, że na podstawie ankiety przeprowadzonej przez firmę oferującą ubezpieczenia zdrowotne Dôvera zdravotná poistovňa a.s. (Dôvera zverejnila proý rebríček kúpel'ov, 2009) stworzono rankingi satysfakcji. Istnieją również ankiety satysfakcji z obiektów noclegowych dla Hotelu Afrodita (zob. Hotel Aphrodite, 2019; Referencie hostí, 2019). W przypadku uzdrowiska Rajecké Teplice dostępne są natomiast nie tylko ankiety (zob. Hodnotenie klientov, 2019), ale również wyniki badań własnych dotyczących satysfakcji klientów (przeprowadzone $\mathrm{z}$ użyciem metod jakościowych).

Autorzy niniejszego artykułu przeprowadzili w uzdrowisku Rajecké Teplice badania satysfakcji klientów w formie ankiety. Następnie wyniki zostały porównane z danymi z uzdrowisk Pieszczany i Brusno. Ankieta składała się z pięciu etapów:

1. Pierwszym krokiem (punkt A kwestionariusza) było wypełnienie kwestionariusza i określenie, które czynniki są najważniejsze w przypadku satysfakcji klientów. Na tym etapie respondentom zaprezentowano 50 czynników mogących mieć wpływ na odczuwanie satysfakcji. Klienci ocenili je i stworzyli listę "top 12" czynników, wymienionych według ważności dla subiektywnego odczuwania satysfakcji z pobytu w uzdrowisku. Na tym etapie ankietowani za najważniejsze uznali: 1) poziom opieki zdrowotnej, 2) atrakcyjność otoczenia uzdrowiska, 3) poziom cen, 4) atrakcyjność środowiska naturalnego wokół uzdrowiska, 5) zaplecze kulturalne uzdrowiska, 6) rodzaje aktywności poznawczej, 7) rodzaje aktywności towarzyskiej, 8) wydarzenia, 9) atrakcyjność miejscowości, 10) możliwość dojazdu do uzdrowiska i dostępność transportu w jego obrębie, 11) obecność klientów międzynarodowych, 12) zaplecze biznesowe.

2. Drugim etapem (punkt B kwestionariusza), po weryfikacji najważniejszych czynników mających wpływ na kształtowanie satysfakcji, było punktowanie, czyli ocena (1-10) konkretnych ośrodków uzdrowiskowych (tj. Rajecké Teplice, Pieszczany i Brusno) przez klientów. Na tym etapie trzy badane kurorty zostały bezpośrednio porównane.

3. W trzecim etapie (punkt $C$ kwestionariusza) klientów poproszono o określenie ogólnego poziomu ich satysfakcji w sześciostopniowej skali.

4. W czwartym etapie (punkt D kwestionariusza) klienci, którzy odwiedzili także inne uzdrowiska poza Rajeckimi Teplicami, zostali poproszeni o uszeregowanie odwiedzonych uzdrowisk według poziomu osiągniętej satysfakcji.

5. Na koniec (punkt E kwestionariusza) poproszono klientów o uszeregowanie uzdrowisk, w których jeszcze nie byli, w kolejności, w jakiej chcieliby je odwiedzić w przyszłości (zakres życzeń).

\section{AUTORSKA KONCEPCJA NARZĘDZIA BADAWCZEGO}

Stworzony przez autorów artykułu kwestionariusz oceny satysfakcji klienta składa się z pięciu części, zawierających następujące polecenia:

A. Wypisz jak najwięcej elementów wpływających na satysfakcję klienta uzdrowiska (np. zadowolenie z zabiegów medycznych oferowanych w uzdrowisku, jedzenia, noclegów, cen itp.) i uszereguj je w kolejności od 1 do 12 według ważności.

B. Oceń poniższe czynniki wpływające na satysfakcję klientów uzdrowisk, przyznając każdemu od 1 do 10 punktów (10 punktów oznacza najwyższy poziom satysfakcji):

1. poziom usług zdrowotnych,

2. atrakcyjność otoczenia uzdrowiska;

3. poziom cen;

4. atrakcyjność środowiska naturalnego, w którym znajdują się obiekty uzdrowiskowe;

5. zaplecze kulturalne uzdrowiska;

6. rodzaje aktywności poznawczej;

7. rodzaje aktywności towarzyskiej;

8. wydarzenia;

9. atrakcyjność miejscowości uzdrowiskowej;

10. możliwość dojazdu do uzdrowiska i dostępność transportu w jego obrębie;

11. obecność klientów międzynarodowych;

12. zaplecze biznesowe.

C. Zaznacz poziom Twojej ogólnej satysfakcji z pobytu w uzdrowisku:

1. pełna satysfakcja,

2. wysoka satysfakcja,

3. średnia satysfakcja,

4. niska satysfakcja,

5. brak satysfakcji,

6. zupełny brak satysfakcji. 
D.Jeśli w przeszłości byłaś klientką / byłeś klientem innych uzdrowisk, uszereguj je pod względem osiągniętego poziomu satysfakcji (w kolejności, w której poleciłabyś/poleciłbyś je innym).

E. Zapisz nazwy innych słowackich uzdrowisk, których jeszcze nie odwiedziłaś/odwiedziłeś, ale chciałabyś/ chciałbyś odwiedzić w przyszłości. Uszereguj je, zaczynając od tego, do którego chciałabyś/chciałbyś pojechać najbardziej.

Twoje obserwacje i uwagi dotyczące satysfakcji klientów uzdrowisk..........

\section{ANALIZA PORÓWNAWCZA}

Analiza porównawcza polegała na zestawieniu wyników ankiety przeprowadzonej przez autorów niniejszego artykułu z podobnymi dostępnymi narzędziami pomiaru satysfakcji. Wybór uzdrowisk poddanych analizie został zdeterminowany przez trzy zasadnicze czynniki:

1. Rajecké Teplice to miejscowość uzdrowiskowa położona w strefie przyległej do Żylina, niedaleko miejsca zamieszkania autorów, a co za tym idzie - są one najlepiej empirycznie przez nich poznane. Jest to również jedno z najbardziej atrakcyjnych uzdrowisk na Słowacji.

2. Pieszczany są najbardziej znaczącym słowackim uzdrowiskiem.

3. Brusno - autorzy badają to uzdrowisko od dłuższego czasu, ich prace znalazły się $\mathrm{w}$ monografii na jego temat (Čuka, 2004), a także mają związane z nim doświadczenia empiryczne. Brusno zostało również wskazane jako uzdrowisko, w którym pobyt przynosi klientom największą satysfakcję.

Na rysunku 2 zaprezentowano stosunek najważniejszych czynników determinujących satysfakcję klientów do ich wagi w przypadku uzdrowisk $w$ Rajeckich Teplicach, Pieszczanach i Brusnie. Co ciekawe, uzdrowisko Rajecké Teplice uzyskało średnio najmniej punktów za zabiegi medyczne (9 pkt; dla porównania w przypadku Pieszczan i Brusna respondenci przyznali po 10 pkt), jednak odchylenie standardowe o wartości 10\% jest pomijalne. Uzdrowisko Rajecké Teplice uzyskało podobne lub wyższe oceny niż pozostałe miejsca, jeśli chodzi o atrakcyjność środowiska naturalnego, w którym są położone kurorty uzdrowiskowe, możliwość dojazdu do uzdrowiska, dostępność transportu w jego obrębie oraz - co zaskakujące - zaplecze biznesowe. Z kolei za największą wadę uzdrowiska Rajecké Teplice w porównaniu do uzdrowiska Pieszczany uznano liczbę turystów międzynarodowych, którzy stanowią jedynie $40 \%$ gości.

Na rysunku 3 pokazano pożądane destynacje. Wśród uzdrowisk, których ankietowani jeszcze nie odwiedzili, lecz które chcieliby odwiedzić w przyszłości, Pieszczany uzyskały 57 wskazań, uzdrowisko Trenczyńskie Cieplice -32 wskazania, zaś uzdrowisko Turčianske Teplice - 28 wskazań. Uzdrowisko Brusno znalazło się na marginesie tabeli życzeń.

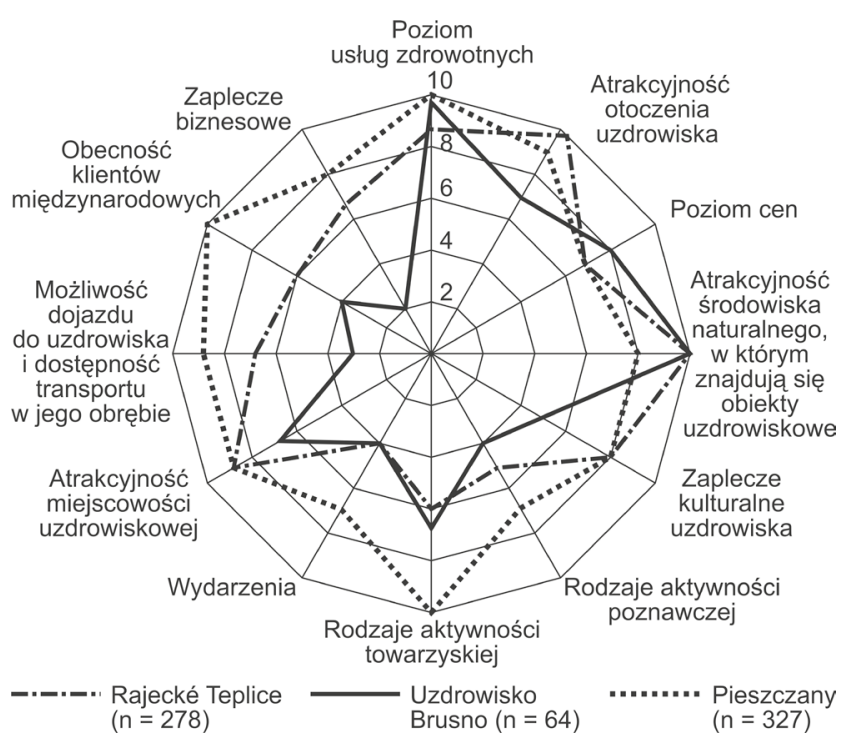

Rysunek 2. Ocena czynników satysfakcji klientów uzdrowisk Źródło: opracowanie własne

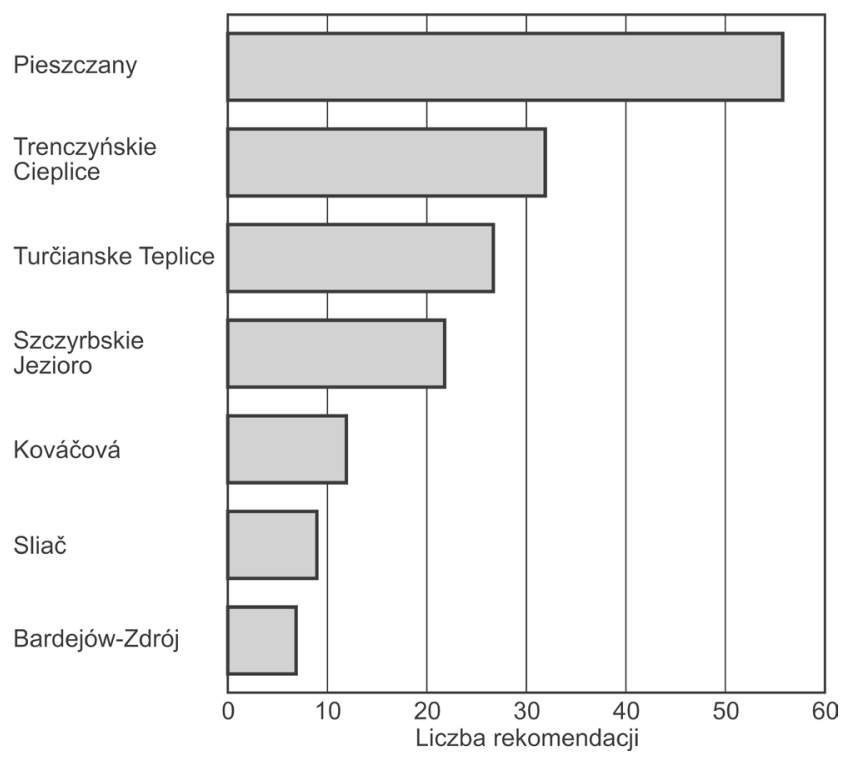

Rysunek 3. Preferowane inne słowackie uzdrowiska Źródło: opracowanie własne

Na rysunku 4 przedstawiono ranking odwiedzonych uzdrowisk uszeregowanych według satysfakcji klientów. Lista jest odzwierciedleniem doświadczeń empirycznych klientów w związku z pobytem w uzdrowisku. Na pierwszym miejscu w rankingu znalazły się uzdrowiska Pieszczany, Rajecké Teplice i Kováčová. Działalność wszystkich trzech koncentruje się wokół leczenia chorób układu ruchu człowieka. Ranking potwierdza, że najlepiej oceniono zabiegi medyczne, 


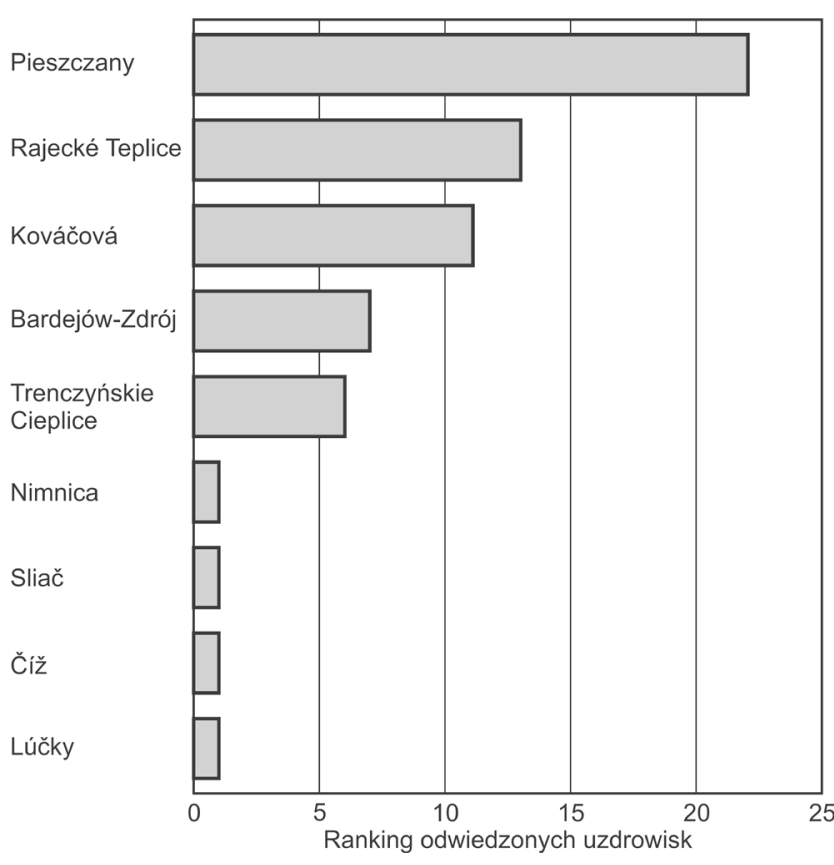

Rysunek 4. Ranking odwiedzonych uzdrowisk według satysfakcji klientów Źródło: opracowanie własne

jak również że klienci mieli pozytywne wspomnienia (Nilson, Mariott, Be, Player, 2017).

Na rysunku 5 zilustrowano skalę ogólnej satysfakcji klientów uzdrowiska Rajecké Teplice w porównaniu do zadowolenia osób przebywających w kurortach $w$ Pieszczanach i Brusnie. W tych trzech uwzględnionych $\mathrm{w}$ badaniu uzdrowiskach przeważała wysoka satysfakcja, kształtująca się na poziomie: $85,25 \%$ w Rajeckich Teplicach, 86,54\% w Pieszczanach oraz $87,3 \%$ w Brusnie. Brak miejsc parkingowych oraz nie-

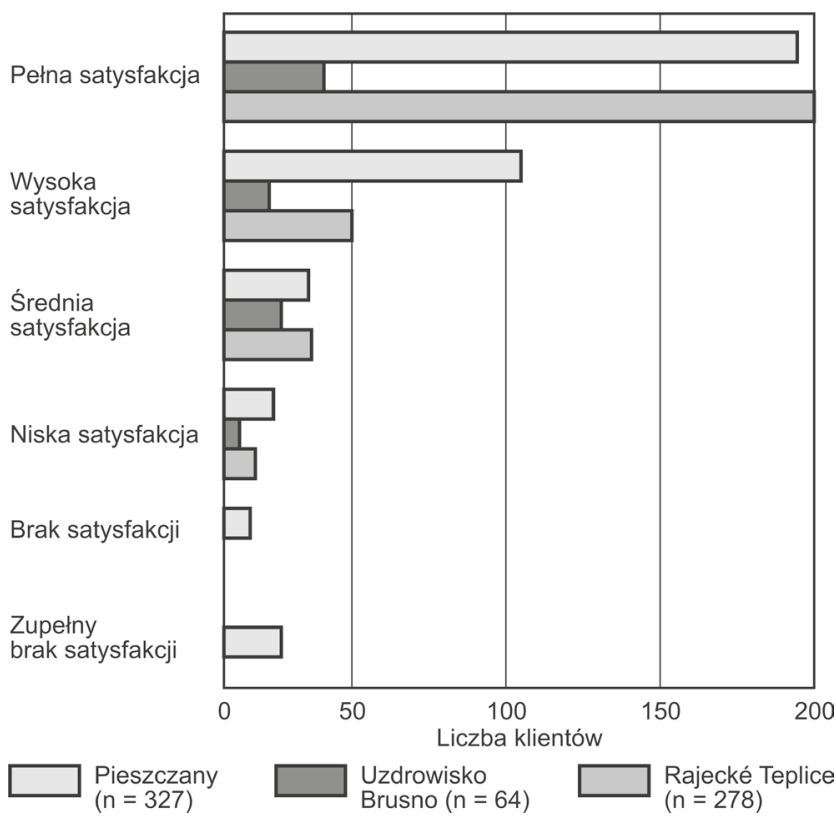

Rysunek 5. Ogólna satysfakcja klienta Źródło: opracowanie własne kompetencja pracowników sektora usług (szczególnie w przypadku usług gastronomicznych) pojawiały się najczęściej w ostatniej części ankiety, gdzie klienci mogli swobodnie opisać swoje pozytywne i negatywne doświadczenia.

\section{WNIOSKI}

W badaniach uwzględniono trzy heterogeniczne uzdrowiska (pod kątem wielkości, funkcji oraz walorów uzdrowiskowych). Okazało się że również satysfakcja klientów w tych uzdrowiskach się różni. Zysk jest po części finansowym odbiciem satysfakcji. W przypadku gospodarki słowackiej nie ma jednak bezpośredniego przełożenia między satysfakcją klienta a zyskiem finansowym. Wiele kurortów uzdrowiskowych jest własnością prywatnych firm, jak na przykład kompleks uzdrowiskowy i hotel Afrodita w Rajeckich Teplicach. Zysk finansowy jest więc wynikiem kombinacji oferowanych produktów oraz inwestycji dokonywanych przez prywatne kierownictwo. W 2018 r. uzdrowisko Rajecké Teplice osiągnęło zysk w wysokości 471833 euro. W obiekcie tym jest zatrudnionych ok. 250 pracowników (Slovenské liečebné kúpele Rajecké Teplice a.s., 2018).

Satysfakcja klientów nie znajduje odbicia w stabilności finansowej czy kapitale akcyjnym. W 2018 r. uzdrowisko Pieszczany osiągnęło ok. 175 tys. euro zysku (Kúpele Pieštany a.s., 2018), uzdrowisko Brusno zaś znajduje się obecnie w stanie upadłości ze stratą rzędu 620 tys. euro (Kúpele Brusno a.s., 2018).

Gdy mowa o porównywanych czynnikach wywołujących satysfakcję klienta, Pieszczany przodują w zakresie atrakcyjności otoczenia uzdrowiska, zaplecza kulturalnego, aktywności poznawczej, rodzajów aktywności towarzyskiej, wydarzeń, atrakcyjności miejscowości, możliwości dojazdu do uzdrowiska i dostępności transportu $\mathrm{w}$ jego obrębie, obecności klientów międzynarodowych oraz obiektów biznesowych. Uzdrowisko Brusno z kolei zostało wyżej ocenione w zakresie atrakcyjności środowiska naturalnego oraz oferowanych cen. Obydwa uzdrowiska uzyskały podobne (najwyższe) noty za poziom oferowanej opieki zdrowotnej.

Po raz ostatni ranking satysfakcji klientów słowackich uzdrowisk został podany do wiadomości publicznej w 2009 r. Opublikowała go firma ubezpieczeniowa Dôvera a.s. Z rankingu wynikało, że najwyższy poziom satysfakcji osiągnęli klienci uzdrowiska Brusno, zaś Pieszczany znalazły się na piątym miejscu. W opracowaniu Nagyovej (2009) poszczególne uzdrowiska uzyskały podobne wyniki: Brusno znalazło się na pierwszym miejscu, a Pieszczany na trzecim.

Firmy zajmujące się ubezpieczeniami na życie nie publikują kolejnych rankingów satysfakcji. Dostępne są jedynie kwestionariusze satysfakcji klientów bądź 
formularze opinii pojedynczych obiektów hotelowych (Maria M - Hotel Rubín, 2019). Kwestia zadowolenia klienta z oferowanych usług jest złożonym problemem, którego rozwiązanie można znaleźć głównie dzięki pomiarom socjologicznym, psychologicznym oraz zaawansowanym pomiarom jakościowym (Angrosino, 2010; Przecławski, 1996).

\section{PRZYPIS}

${ }^{1} \mathrm{~W}$ niniejszym artykule zostały zaprezentowane wyniki projektu badawczego pt. „Zmiany zagospodarowania terenu w słowackim krajobrazie kulturowym oraz prognoza ich dalszego rozwoju" (numer projektu: APVV-18-0185), sfinansowanego przez Słowacką Agencję ds. Badań i Rozwoju.

\section{BIBLIOGRAFIA}

Angrosino, M. (2010). Badania etnograficzne i obserwacyjne. Warszawa: Wydawnictwo Naukowe PWN.

Beach, L.R., Connolly, T. (2005). The psychology of decision making. People in organizations. Londyn: Sage.

Bel, M. (1735). Notitia Hungariae novae historico geographica. Wiedeń: Pavol Straub.

Čuka, P. (2004). Kúpelníctvo a cestovný ruch. W: P. Hronček, A. Choma, L. Chomová, N. Polčák, O. Tomeček (red.), Monografia obce Svätý Ondrej nad Hronom-Brusno (s. 79-87). Brusno: Obec Brusno.

Čuka, P. (2017). Geography of turism of Slovakia. W: K. Widawski, J. Wyrzykowski (red.), The geography of tourism of Central and Eastern European countries (s. 437-467). Springer: Cham. DOI: https://doi.org/10.1007/978-3-319-42205-3_11

Čuka, P., Matušíková, D., Šenková, A. (2013). Thermal parks in Slovakia: Function, analysis, regionalization. W: M. Dej, M. Huculak, W. Jarczewski (red.), Recreational use of geothermal water in Visegrád group countries (s. 150-184). Kraków: Institute of Urban Develompent.

Dôvera zverejnila proý rebríček kúpel'ov (2009). Pobrane z: https:// www.zdravie.sk/clanok/38398/dovera-zverejnila-prvy-rebricek-kupelov (1.08.2020).

Evans, J.St.B.T. (1982). The psychology of the deductive reasoning. Londyn: Routledge \& Kegan Paul.

Evans, J.St.B.T. (2004). Biases in deductive reasoning. W: R.F. Pohl (red.), Cognitive illusions. A handbook of fallacies and biases in thinking, judgement and memory (s. 127-144). Nowy Jork: Psychology press.

Foster, T. (2002). Jak získat a udržet zákazníka. Brno: Computer Press.

Glimcher, P.W., Camerer, P.F., Fehr, E., Poldrack, R.A. (red.) (2008). Neuroeconomics. Decision making and the brain. Nowy Jork: Academic Press.
Gregorová, B. (2010). Analýza vybraných faktorov ovplyvňujúcich vznik a rozvoj cestovného ruchu v Nízkych Tatrách. Geographia Cassoviensis, 4 (1), 53-56.

Heksch, A.F. (1881). Führer durch die Karpathen und Oberungarischen Badeorte. Wiedeń: Hartleben.

Hodnotenie klientov (2019). Pobrane z: http://www.kupeleslovenska. sk/hotel-aphrodite-palace/rajecke-teplice/h55 (13.07.2020).

Hotel Aphrodite (2019). Pobrane z: https://www.booking.com/ hotel/sk/aphrodite.sk.html (2.08.2020).

Hydrologické a fenologické pomery ČSSR (III) (1970). Praga: HMÚ.

Kúpele Brusno a.s. (2018). Pobrane z: https://www.finstat. sk/31642314 (15.07.2020).

Kúpele Pieštany a.s. (2018). Pobrane z: https://www.finstat. sk/34144790 (13.09.2020).

Maria M - Hotel Rubín (2019). Pobrane z: https://www.kupeledudince.sk/references (12.07.2020).

Nagyová, P. (2009). Pobrane z: https://dennik.hnonline.sk/ slovensko/209342-rebricek-kupelov-boduje-stred-slovenska (12.09.2020).

Najlepšie hodnotené kúpele na Slovensku (2019). Pobrane z: https:// www.sorger.sk/kupele?sort=reviewsm (2.09.2020).

Nilson, P., Mariott, L. (2017). Be a player. A breakthrough approach to playing better on the golf course. Londyn: Atria Books.

Przecławski, K. (1996). Człowiek a turystyka. Zarys socjologii turystyki. Kraków: ALBIS.

Rajecké Teplice liečebný pobyt (2019). Pobrane z: http://www.kupeleslovenska.sk/preventivny-liecebny-balik/rajecke-teplice/ p7306 (13.07.2020).

Referencie hostí (2019). Pobrane z: https://www.kupeledudince. sk/references (20.07.2020).

Rudnicki, L. (2015). Wpływ produktu turystycznego na zachowania rynkowe konsumentów. Zeszyty Naukowe Małopolskiej Wyższej Szkoły Ekonomicznej w Tarnowie, 26 (1), 121-128.

Slovenské liečebné kúpele Rajecké Teplice a.s. (2018). Pobrane z: https://www.finstat.sk/31642284 (25.07.2020).

Szwarc, P. (2005). Research customer satisfaction \& loyalty: How to find out what people really think. Londyn-Filadelfia: Kogan Page Limited.

Szymańska, B. (2013). Satysfakcja komercyjnego klienta usług sanatoryjnych w Polsce. W: W. Grzegorczyk (red.), Marketing w obliczu nowych wyzwań rynkowych. Księga jubileuszowa z okazji 70-lecia Profesora Gregora (s. 229-242). Łódź: Wydawnictwo Uniwersytetu Łódzkiego. DOI: https://doi. org/10.18778/7969-046-6.19

Tatrabanka používa AI technológiu (2017). Pobrane z: https:// www.tatrabanka.sk/sk/blog/tlacove-spravy/tatra-banka-pouziva-ai-technologiu-ktora-rozpozna-spokojnost-klienta/ (27.05.2020).

Walas, B. (2018). Badanie satysfakcji kuracjuszy uzdrowiska Rabka-Zdrój metodą Kano. Biuletyn Przestrzennego Zagospodarowania Kraju Polskiej Akademii Nauk, 269, 143-156.

Artykuł wpłyną: 9 czerwca $2020 \mathrm{r}$. Zaakceptowano do druku: 30 listopada $2020 \mathrm{r}$. 